\title{
VALUE STREAM MAP AND VISILEAN® FOR PREFABRICATED CONCRETE PANELS MANAGEMENT
}

\author{
Julia Kanai ${ }^{1}$ and Patricia Stella Pucharelli Fontanini
}

\begin{abstract}
The lack of process flow planning causes waste of time and material. The value stream map helps workers understanding the flow, identifying waste and planning for the future state. Visilean ${ }^{\circledR}$ helps automate production control. The main objective of this work is to propose a method to improve process flow planning of prefabricated concrete panels based on the application of Value Stream Map and Visilean ${ }^{\circledR}$ to manage the movement of parts in the factory. Results show value stream maps for project, production and installation processes allowing suggestions for improvements to operational procedures. There are four scenarios in this research to achieve a just-in-time method. Comparing the scenarios, the longest scenario is the Current one, which is based on the data collected in the factory without any changes on the flow. The Future 1 scenario had a small improvement compared to the current scenario. The Future 2 scenario reduced $25 \%$ of the time of the current scenario. The Ideal scenario has reduced more than $50 \%$ of the time of the current scenario. This research showed that the Value Stream Map and Visilean ${ }^{\circledR}$ are great tools to use in managing the flow of prefabricated panels.
\end{abstract}

\section{KEYWORDS}

Lean construction, production pull, job-sequencing, value stream map, Visilean $®$

\section{INTRODUCTION}

Waste of time and waste of material are the problems in construction due to the lack production flow planning. It is important to improve productivity, so the factory can produce more in less time, then the company make more money. Prefabrication has improved productivity and reduced waste of material and labor, because it has more control in factory than in construction site. However, with the right lean tools they can obtain even better results. According to Howell (1999), Lean Construction is the result of applying a new philosophy for production management for construction. The essential characteristics of lean construction include a clear set of objectives for the delivery process, aimed at maximizing customer performance at the project level, concurrent product and process design, as well as the application of production control from conception final customer delivery. Luo et al. (2005) applied the lean concept to prefabrication and stated that lean could contribute to improving quality, improving

1 Sr. Lecturer in Construction, Civil Engineering, State University of Campinas, Campinas, SP, 13083889, Brasil, j192221@dac.unicamp.com, orcid.org/0000-0002-4549-8848

2 Prof., Civil Engineering, Construction, LABTEC, State University of Campinas, Campinas, SP, 13083889, Brasil, patricia@fec.unicamp.br, orcid.org/0000-0002-7532-7505 
supply chain and reducing waste. Some recent studies also showed that the lean concept can reduce $8 \%$ of carbon emissions in prefabricated plants, improving the layout of the construction site and the supply chain (Wu and Low 2011, 2012).

The "lean" concept started in a manufacturing environment, more specifically in the automobile industry, by engineer Ohno, the creator of the Toyota Production System, in the 1980s (Picchi 2003). The objective of this system is the absolute elimination of waste, supported by two pillars: just-in-time and autonomation. Just-in-time is the system in which something is only produced when it is necessary. Autonomation is the process of automation of processes with human interference allowing automatic stopping of machines, preventing the production of errors in series (Ohno 1988).

Despite the differences between the manufacturing environment and the construction, there are great possibilities for applying Lean Thinking in the design, supply, and workflow. For project flows, a value stream map can improve identification of customer requirements, simultaneous engineering, decision-making and integration of specialized subcontractors. Examples of applicability for supply flows are analysis of the supply chain and its waste, partnership with suppliers, mapping of flows and just-in-time system with suppliers. In the workflow, managers can use production cells, poka-yoke to avoid errors and defects, process review, standardization and pull production (Picchi 2003). Lean construction also eliminates waste from processes to improve construction planning and management and then reduces material waste by 64\% (Nahmens and Ikuma 2012).

\section{LEAN CONCEPTS}

\section{Process SYNCHRONIZATION}

The use of prefabricated building systems requires close coordination and synchronization between the project, the factory, and the construction sites so that the assembly process is not interrupted and the stock level is lower. Typically, prefabricated building systems face a high level of uncertainty, due to the lack of predictability of the design process, long transport distances between the factory and construction sites, interference from previous construction stages, unreliable installation plan between other factors (Penaloza et al. 2016).

Matt et al. (2014) developed research using a concept of alignment from manufacturing to construction with two control circuits, one to activate the pre-production of components and the other to release the finished components according to the progress of the construction, triggering the assembly final process. The factory sends the components to the construction site within short intervals. The last production process (assembly) defines the point of decoupling from manufacturing to construction. To reduce production time, the components are prefabricated and stored in a lean production supermarket. As soon as the construction site is ready for installation, the factory starts the production of the components. Production is pulled from the construction site, thus allowing the elimination of intermediate stocks.

\section{JUST IN TIME}

The just-in-time (JIT) term means that the suppliers deliver the correct parts on the construction site when they need it and only in the required quantity (Ohno 1988). JIT helps to reduce energy consumption by eliminating unnecessary transportation with storage because the production uses the material immediately upon arrival. 
The steps for the success of the just-in-time implementation follow: a) Work together with the supplier, design new processes; b) Assign the engineer half the time at the construction site and half the time at the plant, to complete the manufacturing process; $c$ ) Analyze the problems encountered during the installation, identify the root causes and the changes to be made in the plant to improve the quality and facilitate the installation; d) Analyze the coordination for manufacturing, transportation, storage, and installation daily (Cossio and Cossio 2012).

\section{CONTINUOUS FLOW}

Implementing product simplification and the work process is important to organize the factory layout to avoid interrupting the processes. Preventive maintenance is also important to achieve uninterrupted workflow (Wu et al. 2013). After the introduction of the continuous, the product design time drops dramatically, products that took years to manufacture, now execute in months, and orders that took days to send can now arrive in hours (Womack and Jones 1996).

\section{VALUe STREAM MaP}

The Value Stream Map (VSM) is a tool that helps to understand the flow of material and information, as the product follows the Value Flow. Value flow is the set of all specific actions necessary to take a specific product through the three critical management tasks in any business: the problem-solving task, the information management task and the physical transformation task (Fontanini 2004). This flow goes from consumer demand to raw material. When considering the value flow perspective, it means taking into account a broader framework, not only its processes, not only optimizing parts, improving the whole, but going all the way from raw materials to the consumer (Rother and Shook 2003).

There are 3 positive points of the VSM. First, the map helps you visualize the processes and see the whole flow. Second, it helps to identify waste and its sources. Third, the VSM forms the basis for an implementation plan showing the relationship between the Information Flow and the Material Flow. This relationship is important to measure the system and create a sense of urgency, with measurements and comparisons before and after (Rother and Shook 2003). With this comparison, a future state of the system is defined, in which one seeks to implement the continuous flow (Rother and Shook 1999). The VSM was initially proposed to model production systems in a factory (Rother and Shook 1999), and then extended to supply chain modeling (Womack and Jones 1996). There are also publications on the application of this tool in administrative processes (Picchi 2002; Tapping and Shuker 2003; Reis 2004). In Brazil, Fontanini and Picchi (2004) applied VSM in the aluminum supply chain, from the raw material to the on-site installation of aluminum components, to identify waste and to help design production systems incorporating the lean concept.

\section{METHOD}

The research was developed at a company in São Paulo (Brazil). The method started from the investigation of the flow of concrete panels produced in the factory (in a controlled environment), followed by transport to the construction site, the flow of information on design, production, and assembly of the prefabricated parts will also be investigated. The human resource involved was part of the investigation. The chosen material, prefabricated concrete panel, has a production line based on the specified design and quantities defined 
by the factory manager. The authors classify this research as a case study since they observed the material and information flow of a real construction.

For the definition of the current scenario, the authors had an interview with the design engineers, production engineers, and construction engineers. They had observed the project flow for 3 days. The production flow had a data collection using a spreadsheet to identify the time of each part of the production process. The authors had collected data on factory flow for 4 days of observation. In this way, data collection got an average duration of each stage. After they got the average time to conclude each part of the flow (design, production and assembly), they were able to make a schedule. On the schedule, they had planned which panels would be designed, produced or installed per day. This schedule helped to make the value stream map for the current schema of the company and from this map, the authors were able to make all the future maps to improve the flow. They put the same schedule on Visilean ${ }^{\circledR}$ and linked each day of the schedule with the panels that must be made that day. Visilean ${ }^{\circledR}$ helped to control the flow electronically.

\section{SCENARIOS}

The scenarios' names and their respective descriptions were based on Jones and Womack's (2004) handbook, making the necessary modifications to adapt to the production of prefabricated panels instead of the automotive component. The current scenario represents the flow of value obtained from data collection at the factory and interviews with the company's engineers. Future scenario 1 has a system pushed between the design, production and construction processes, with the formation of stocks between the processes. In this way, production can only start when all the project details for all panels are ready and the assembly can only start after the production of all the panels. Future scenario 2 has a smooth and leveled pull system with frequent deliveries between processes and the insertion of supermarkets instead of stocks. Finally, for the ideal scenario, the objective of lean thinking is to achieve just in time by providing customers the product they want, when they want it and in the right amount.

Table 1: Description of purposed scenarios

\begin{tabular}{|c|c|c|}
\hline Scenarios & Value flow & Description \\
\hline Current scenario & Real system & $\begin{array}{l}\text { Value stream obtained from factory data collection and } \\
\text { interview with company engineers. }\end{array}$ \\
\hline Future scenario 1 & Pushed system & $\begin{array}{l}\text { System pushed between processes of design, } \\
\text { production and work, with storage formation among the } \\
\text { processes. }\end{array}$ \\
\hline Future scenario 2 & Pull system & $\begin{array}{l}\text { Pull system with frequent deliveries between production } \\
\text { and assembly processes and insertion of supermarkets } \\
\text { instead of stocks. }\end{array}$ \\
\hline Ideal scenario & Just in time system & $\begin{array}{l}\text { Lean thinking goal: to provide customers with product } \\
\text { they want, when they want it, which is to apply just in } \\
\text { time throughout all the process. }\end{array}$ \\
\hline
\end{tabular}

For all scenarios, we considered 1 project engineer, a production team with 12 people, an assembly team with 3 people and the availability of 3 trucks per delivery day. So the number of project details per day was 10 panels, the production per day was 7 due to the demand for other works and the assembly per day was 10 panels. 


\section{RESULTS}

The results begin with a description of the current scenario studied at the company. With the interview with the engineers was possible to obtain the project flow and assembly flow. The production flow had a checklist for observation of the time cycle of each stage. Based on the data from the three flows collected, there are value stream maps for each scenario: current, the Future1, Future 2 and Ideal. Future 1 and Future 2 scenarios are intermediate scenarios to achieve the Ideal scenario. Finally, VisiLean ${ }^{\circ}$ was the tool to control and to monitor panel flows.

\section{CURRENT SCENARIO}

The building monitored in this research is shed. The 3D model in IFC format (Revit) of the shed was supplied by the company as showed in Figure 1, as well as the number of panels, the location of each panel and the characteristics of each panel (weight, volume, length, name, etc.). The contract started in June 2018 and the delivery deadline was October 19, 2018. Figure 1 shows the 3D model of the building from two angles. The shed consists of two parts: a larger shed and an annex. The largest building is 90 meters long, 63.05 meters wide and 12.50 meters high. The annex is 14.90 by 56.60 meters and 11.40 in height. The distance between the two is 13.05 meters. The shed has a total of 161 panels.

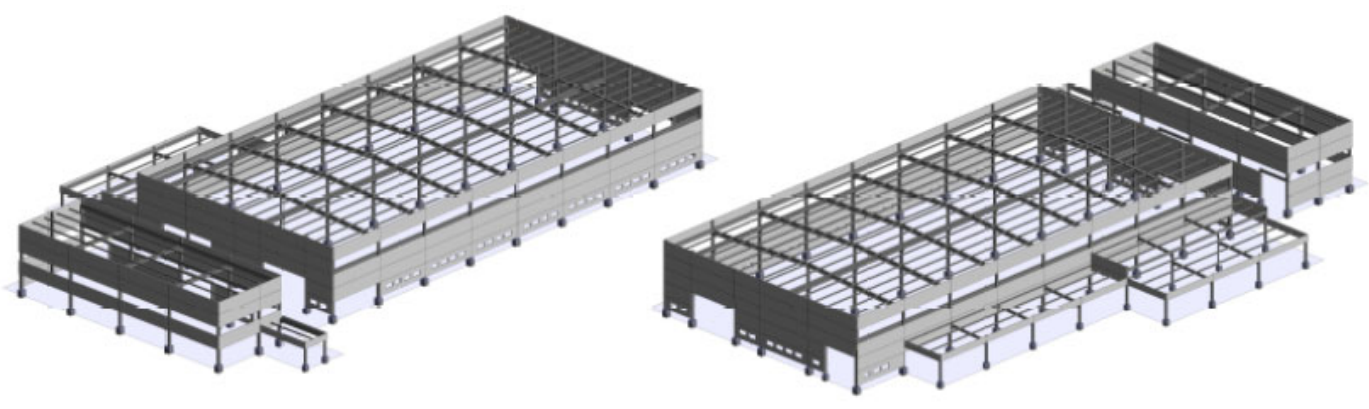

Figure 1: 3D model of shed

The design team does 10 panels detailing per day and per engineer. Therefore, the details can be ready one day before the production of the respective panels, which is the minimum time. In the current scenario, 161 panels would take 17 days to complete the detailed design of all panels.

The production sequence consists of framework, cleaning formwork, assembling the formwork, putting framework on formwork, concreting, vibration, polishing, curing, withdrawing and shipping. According to the company, the production must be mixed among other works, so the maximum number of panels to produce for this shed is 7 . The production of the 7 panels is ready in one day, but the panels have more than 24 hours of curing. After curing, the panel is taken to the stock, where it remains until it goes to the construction site.

Each panel takes about 1 hour to install. First, it takes 15 minutes to secure the crane. Then, the lifting takes another 5 minutes and it takes 10 minutes to position the panel. Finally, the panel takes another 30 minutes to fix. The assembly team can install 10 panels per day. 


\section{Current scenario map}

The value stream map of the current scenario is in Figure 2 according to the company's schedule dates. On the current map, the flow is pushed with lots of 10 detailed panels every 8 hours, lots of 7 panels per day of production and lots of 10 panels assembled per day on site. In the production stage, a waiting time of 24 hours was considered between concrete curing and withdrawal processes.

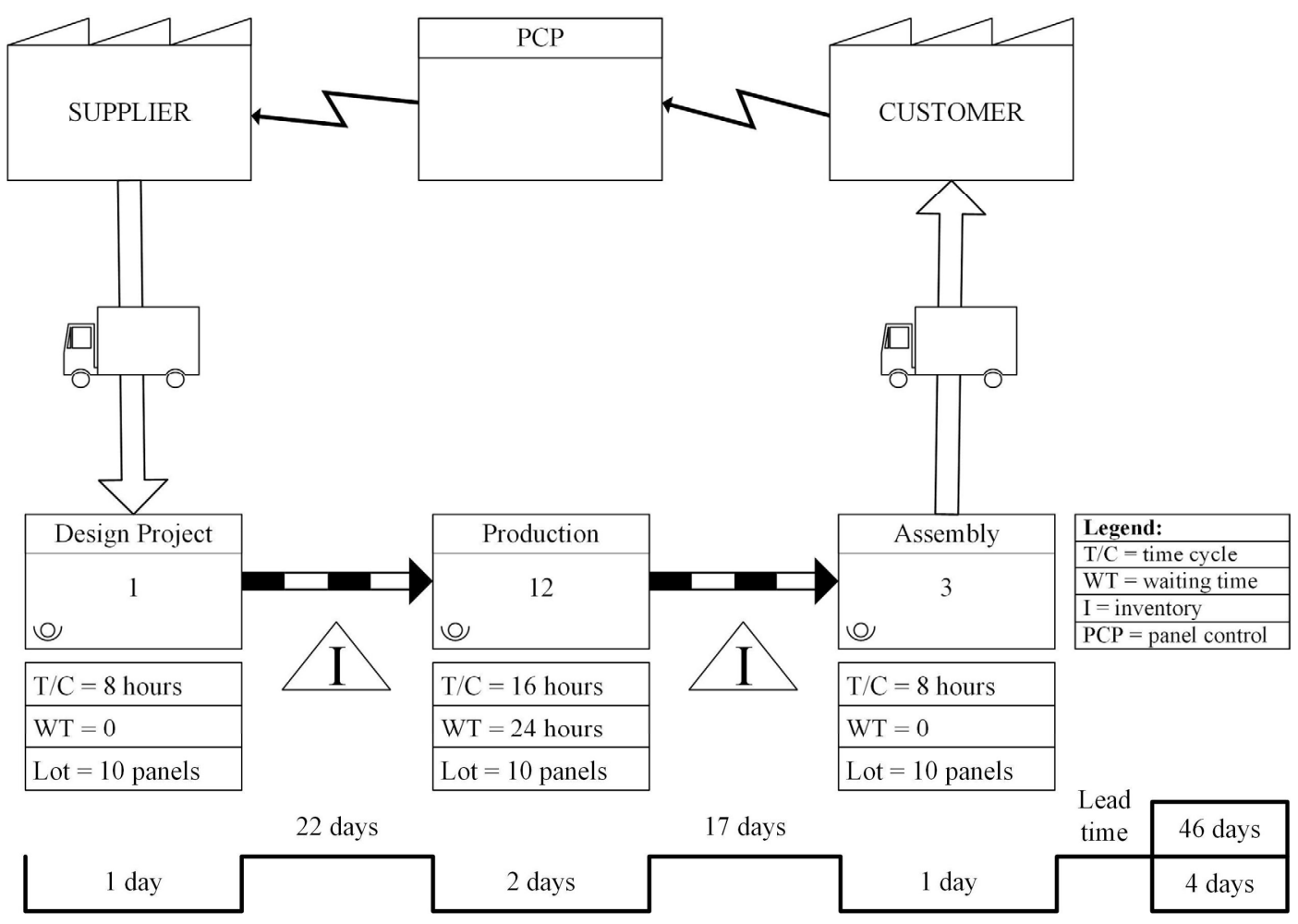

Figure 2: Current scenario map

\section{FUTURE SCENARIO 1}

For future scenario 1, the flow of materials continues to be pushed and with the formation of stock of all parts before moving on to the next stage. The purpose of this analysis is to observe how many days would take in a conventional system in which each step needs to be completed in full before moving on to the next step. Therefore, the observed work has 161 panels, detailed designs of all panels must be ready before starting production, then the factory must produce all panels before sending it to the construction site.

Figure 3 shows how long the daily lots for each process need to be in stock until the time to finish the 161 panels and move on to the next process. From design to production, it takes 16 days of inventory before moving on to production. From production to assembly, it takes 22 days on inventory to produce all the panels before they go to the construction site. 


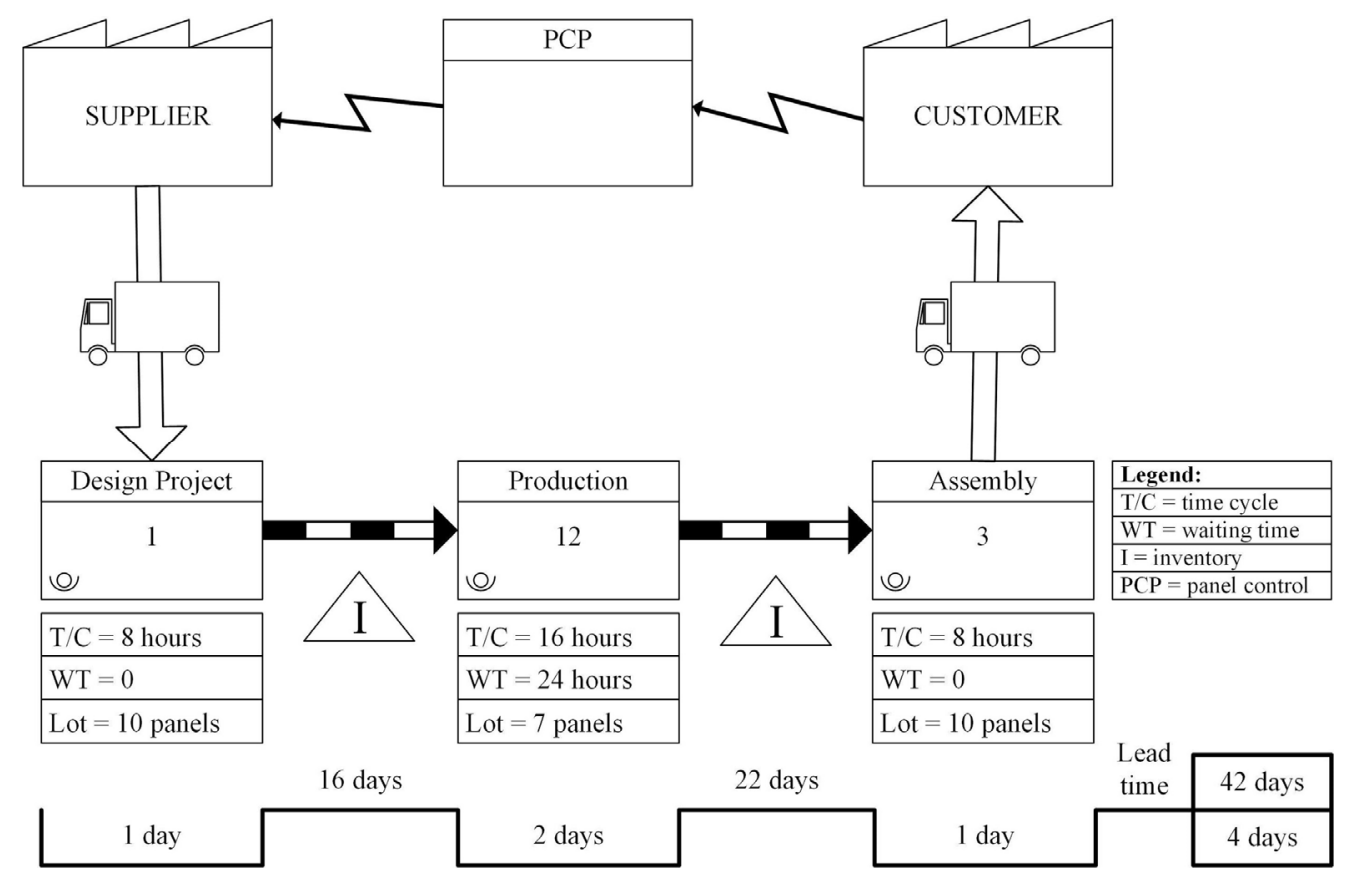

Figure 3: Future scenario 1 map

\section{FUTURE SCENARIO 2}

In future scenario 2, there is a just-in-time system between production and assembly, eliminating stock between the two processes. Therefore, the assembly lot must be the same as the production capacity, 7 panels. Thus, everything produced in one day goes to the assembly the next day. The production of each panel takes 2 days before the assembly, which is the minimum time to produce, cure, dry and load the truck. The project schedule for this scenario follows the same concept as the future scenario 1, in which the last day of the project must be one day before production starts and engineers design 10 panels per day.

The value stream map of future scenario 2 is in Figure 4. Eliminating inventory reduces storage costs, unnecessary movement and frees up space. On this map, the push arrow between the production and assembly process has been replaced by a system pulled level with a supermarket to eliminate inventory. The supermarket helps to create a planned inventory more organized and to control the production between processes. Upon receiving the panels at the construction site, an electronic withdrawal kanban card is sent to production. In the research, VisiLean ${ }^{\circledR}$ is the electronic system that informs the withdrawal of the panel symbolized by the kanban withdrawal card in the flow map. 


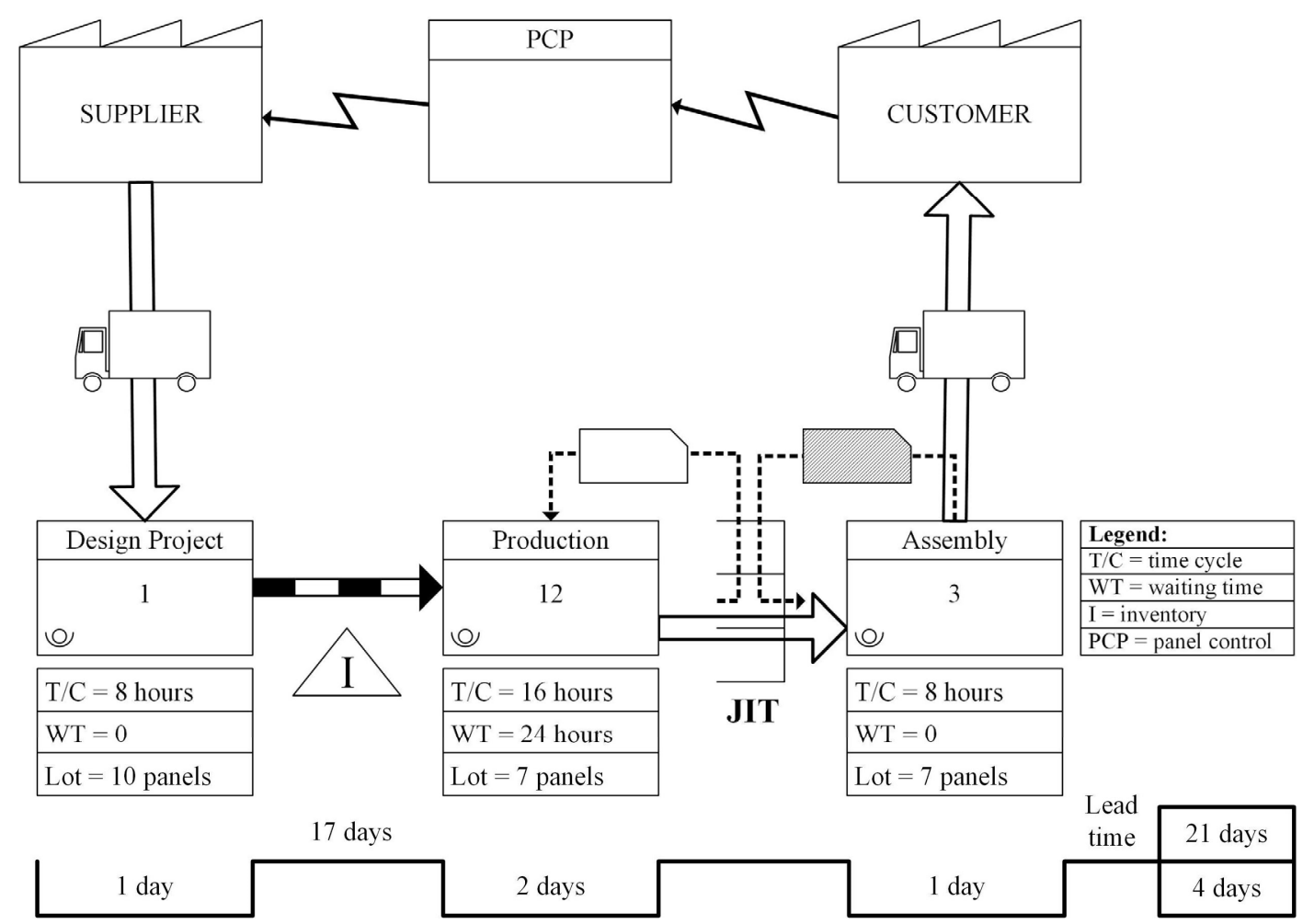

Figure 4: Future scenario 2 map

\section{IDEAL SCENARIO}

In the ideal scenario, the entire flow is just-in-time. The production controls the lots because only 7 panels can be produced per day. To maintain this demand without stocks, it is necessary to prepare projects only for the amount produced the next day and assemble only what is produced. Therefore, the assembly schedule has only 7 panels per day. For the production schedule, it is important to emphasize again that the panels take two days to be ready because of curing time. That is the minimum time between production and assembly. The value stream map of the ideal scenario is shown in Figure 5. In this map, there is a leveled system with supermarket between the design and production stages as well, also symbolizing the just-in-time flow and eliminating the stock. This system would be advantageous for eliminating inventory costs. In addition to sending the electronic withdrawal kanban card through VisiLean ${ }^{\circledR}$, there is a collection box for kanban cards to be sent to the company's production control plan (PCP). This will assist in controlling finished parts at each stage. 


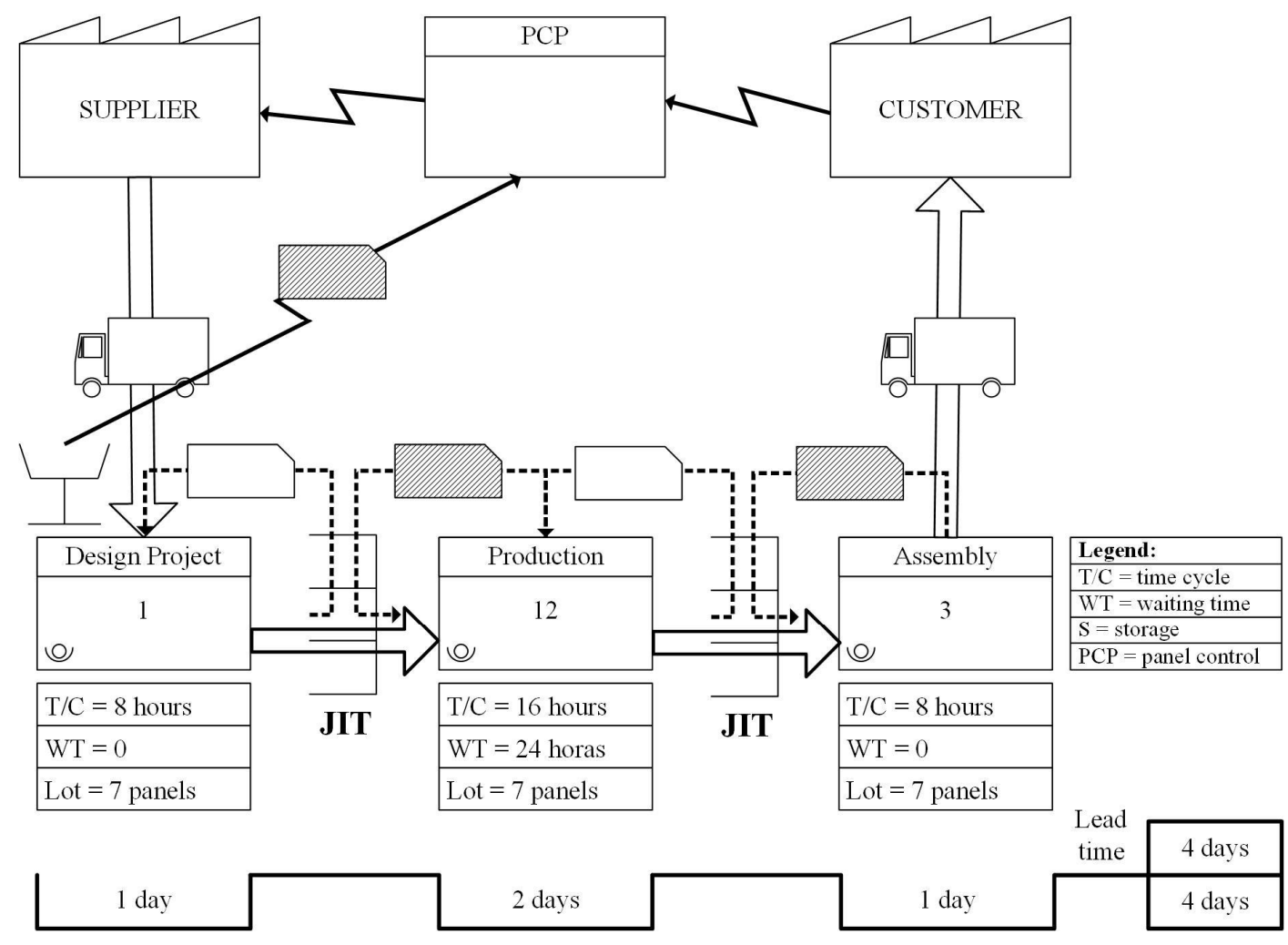

Figure 5: Ideal scenario map

\section{VISILEAN}

Visilean ${ }^{\circledR}$ provided the visualization of the $3 \mathrm{D}$ model of the building, the control of the value flow and the comparison of the scenarios. The 3D model facilitated the visualization of the location of all the prefabricated panels. The Visilean ${ }^{\circledR}$ app on mobile helped to control the production of the panels. Every complete panel was updated via the mobile app. This improved communication of the flow, so the teams were aware of the completion of each stage. Visilean ${ }^{\circledR}$ allowed the insertion of the schedules of the four proposed scenarios, so it is possible to compare their duration. As there were all the dates scheduled for the start of design, production, and assembly in the mobile app, it was easier to follow the schedule to achieve just in time. Figure 6 shows the Visilean ${ }^{\circledR}$ web page. 


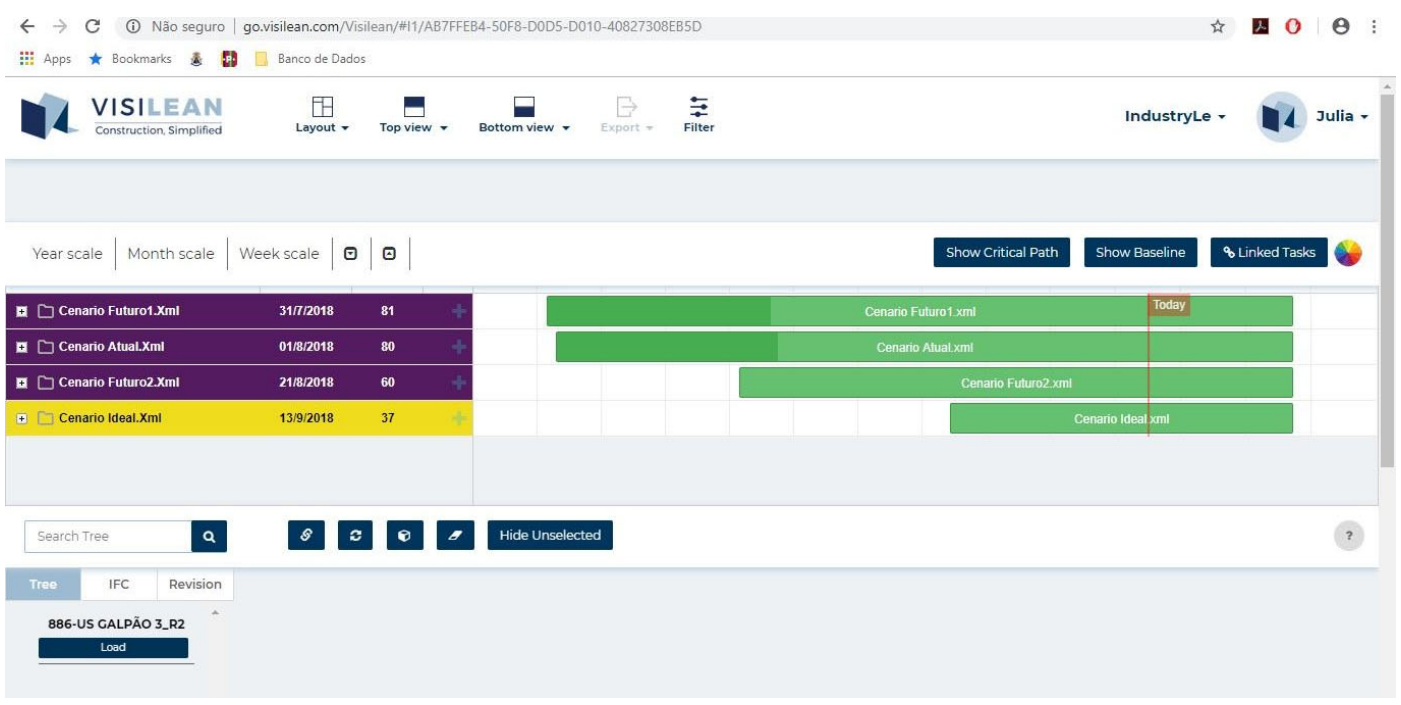

Figure 6: Visilean ${ }^{\circledR}$ web site

\section{DISCUSSION}

On Visilean $囚$, we can compare the duration to finish all panels in all scenarios. The longest scenario is the Current, but it is almost the same time as the Future 1 scenario, which is the system pushed. The Future 1 scenario had a small improvement compared to the current scenario. As the Future 1 scenario is all pushed, it can be concluded that the current scenario is practically pushed. Future scenario 2, on the third line, reduced $25 \%$ of the time of the current scenario, which means that transforming the process between manufacturing and assembly in just-in-time reduces the total time. The Ideal scenario, in the fourth line, has reduced more than $50 \%$ of the time of the current scenario, meaning that it is the most optimized scenario possible for the design, production, and assembly of the company. This means that the current schedule planning can be optimized and reduced. Another point is that the current flow of the company can be considered pushed by the planned time. The ideal scenario can be considered utopian because it depends on all conditions being perfect. As the factory works with a diversity of design, double walls, different works, different finishes and variability of deliveries for both customers and suppliers, it is difficult to achieve the ideal scenario. On the other hand, it is important to have an excellent reference point to be in constant improvement to achieve this goal. Figure 7 shows a comparison of the scenarios in Visilean.

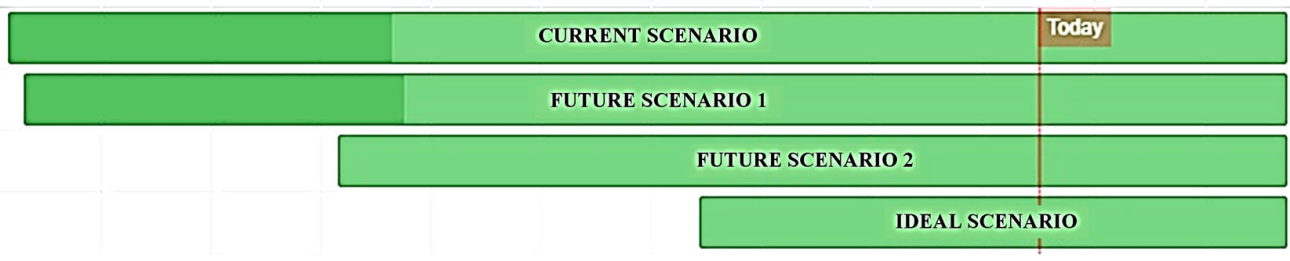

Figure 7: Comparison of scenarios 
On Table 1, we can see a summary of inventory times and lead times for each scenario and for each lot of panel. Each value stream map showed the lead time for lots of 10 or 7 panels. And Visilean showed the schedule for all panels.

Table 1: Summary of inventory times and lead times

\begin{tabular}{|c|c|c|}
\hline Scenarios & Inventory time & Lead time \\
\hline Current & 39 & 46 days \\
\hline Future 1 & 38 & 42 days \\
\hline Future 2 & 17 & 21 days \\
\hline Ideal & 0 & 4 days \\
\hline
\end{tabular}

There are some limitations of this study such as panels were the only product observed and the factory has other products on material flow like columns and beams. Other limitation is the study observed only one building panels production. However, there were other buildings production at the same time of the study, so the study reflects only part of the factory's productivity.

\section{CONCLUSIONS}

In theory, the contribution of this research was to achieve just-in-time gradually using four scenarios in Value Stream Maps. The Value Stream Maps helped to manage the design, production, and assembly cycle times. This research showed that the Value Stream Map is a good tool to use in managing the flow of prefabricated panels. In practice, the paper also contributed to show the use of Visilean ${ }^{\circledR}$ for precast panel production management. Therefore, operators were able to view production times and services, as well as their sequence in real-time. The best visualization of processes and control has a great impact on the quality of the final product, as well as, cost reduction, waste reduction, meeting the deadline in a given time and improving communication. Visilean ${ }^{\circledR}$ helped to control and to monitor, electronically, the stages of design, production, and assembly. Also, the communication between stages had an improvement as well as information flow.

Despite the factory is remarkably automated, it is important to have continuous improvement, as seeking new updates will ensure that the company is always modern and in a good competitive position in the market. For future research, the suggestion is to include RFID or the Internet of Things to have greater control of flow management.

\section{ACKNOWLEDGMENTS}

The authors would like to thank the Coordenação de Aperfeiçoamento de Pessoal de Nível Superior (CAPES), a foundation linked to the Brazilian Ministry of Education that operates in the expansion and consolidation of stricto sensu graduate programs in all Brazilian states, for funding this research.

\section{REFERENCES}

Cossio, J. G. and Cossio, A. G. (2012). "Application of just in time to the fabrication and installation of prefabricated concrete facades in buildings." Proc. $20^{\text {th }}$ Annual Conference of the International Group for Lean Construction, San Diego, USA. 
Fontanini, P. S. P. (2004). "Mentalidade enxuta no fluxo de suprimentos da construção civil - aplicação de macro mapeamento na cadeia de fornecedores de esquadrias de alumínio." MSc Thesis, Civil Engineering, State University of Campinas.

Fontanini, P. S. P., and Picchi, F. A. (2004). "Value stream macro mapping-A case study of aluminum windows for construction supply chain." Proc. 12th Annual Conference of the International Group for Lean Construction, Elsinore, Denmark.

Howell, G. A. (1999). "What Is Lean Construction." Proc. $7^{\text {th }}$ Annual Conference of the International Group for Lean Construction, California, USA.

Jones, D. T., and Womack, J. P. (2004). Enxergando o Todo mapeando o fluxo de valor estendido. Ed. Lean Institute Brasil, São Paulo, Brazil.

Luo, Y., Riley, D., and Horman, M. J. (2005). "Lean principles for prefabrication in green design-build (GDB) projects." Proc. 13th Annual Conference of the International Group for Lean Construction, Sydney, Australia.

Matt, D. T., Dallasega, P., and Rauch, E. (2014). "Synchronization of the manufacturing process and one-site installation in ETO companies." Procedia CIRP, 17 457-462.

Nahmens, I., and Ikuma, L.H. (2012). "Effects of Lean Construction on Sustainability of Modular Homebuilding." Journal of Architectural Engineering, 18(2) 155-163.

Ohno, T. (1988). Toyota Production System: beyond large-scale production. Cambridge, MA: Productivity Press.

Penaloza, G. A., Viana, D. D., Batagling, F. S., Formoso, C. T., and Bulhões, I. R. (2016). Guidelines for Integrated Production Control in Engineer-to-Order Prefabricated Concrete Building Systems. Proc. 24 $4^{\text {th }}$ Annual Conference of the International Group for Lean Construction, Boston, USA, pp. 103-112.

Picchi, F. A. (2002). Lean na Administração. LEAN SUMMIT. 2002, Gramado, Brasil. Lean Institute Brasil.

Picchi, F. A. (2003). "Oportunidades da aplicação do Lean Thinking na construção." Ambiente Construído, 3(1) 7-23.

Reis, T. dos. (2004). "Aplicação da Mentalidade Enxuta no Fluxo de Negócios da Construção Civil a Partir do Mapeamento do Fluxo de Valor." MSc Thesis, Civil Engineering, State University of Campinas.

Rother, M., and Shook, J. (2003). Aprendendo a enxergar: mapeamento do fluxo de valor para agregar valor e eliminar o desperdício. São Paulo, Lean Institute Brasil.

Rother, M., and Shook, J. (1999). Aprendendo a Enxergar: mapeando o fluxo de valor para agregar valor e eliminar o desperdício. São Paulo, Lean Institute Brasil.

Tapping, D., and Shuker, T. (2003). Value Stream Management for the Lean Office: 8 steps to planning, mapping, and sustaining lean improvements in administrative areas. New York, Productivity Press.

Womack, J. P., and Jones, D. T. (1996). A Mentalidade Enxuta nas empresas: elimine o desperdício e crie riqueza. Tradução de Ana Beatriz Rodrigues e Priscila Martins Celeste. 5. ed. Rio de Janeiro: campus.

$\mathrm{Wu}, \mathrm{P}$., and Low, S. P. (2011). "Lean and green: emerging issues in the construction industry." Proc. of the EPPM Conference, Singapore.

Wu, P., and Low, S. P. (2012). "Lean management and low carbon emissions in precast concrete factories in Singapore." Journal of Architectural Engineering, 18(2) 86-176.

Wu, P., Low, S. P., and Jin, X. (2013). "Identification of non-value adding (NVA) activities in precast concrete installation sites to achieve low-carbon installation." Resources, Conservation and Recycling, 81 60-70. 